\title{
Surveillance of aseptic central nervous system infections in Poland: is it meeting its objectives?
}

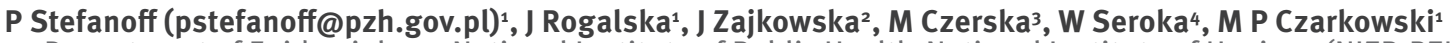

1. Department of Epidemiology, National Institute of Public Health-National Institute of Hygiene (NIZP-PZH), Warsaw, Poland

2. Department of Infectious Diseases and Neuroinfections, Medical University in Bialystok, Poland

3. Department of Neurology, Mazovian Regional Hospital in Siedlce, Poland

4. Department-Centre of Monitoring and Analyses of Population Health, National Institute of Public Health-National Institute of Hygiene, Warsaw, Poland

Stefanoff P, Rogalska J, Zajkowska J, Czerska M, Seroka W, Czarkowski MP. Surveillance of aseptic central nervous system infections in Poland: is it meeting its objectives?

Euro Surveill. 2011;16(29):pii=19924. Available online: http://www.eurosurveillance.org/ViewArticle.aspx?Articleld=19924

In Poland, a surveillance system capturing generic information on both diagnosed and undiagnosed aseptic central nervous system infections $(A C I)$ has been in operation since 1966. This study evaluates to what extent the $\mathrm{ACl}$ surveillance is able to meet its objectives to monitor $\mathrm{ACl}$ trends and to detect signals of public health importance such as enteroviral outbreaks, tick-borne encephalitis (TBE) endemic foci, poliovirus appearance or emergence of new neurotropic viruses. Between 2004 and 2008, aetiology was established for $17 \%$ of $\mathrm{ACl}$ cases. Of the 1,994 reported $\mathrm{ACl}$ cases, 232 (11.6\%) were diagnosed with TBE virus, $46(2.3 \%)$ with enterovirus, 35 (1.8\%) with herpesvirus, and $32(1.6 \%)$ had other viral causes such as Epstein Barr virus or adenovirus. The system's performance varied between the provinces, with the frequency of suspected $\mathrm{ACl}$ cases referred for viral aetiology investigation in 2008 ranging from 1.98 to 285.4 samples per million inhabitants. The sensitivity of physicians' reporting, estimated as the proportion of hospitalised $\mathrm{ACl}$ cases reported to the surveillance system, was $48 \%$ nationally, with vast regional differences (range 30-91\%). To conclude, the $\mathrm{ACl}$ surveillance system in Poland does currently not meet its objectives, due to limited availability of aetiological diagnosis and microbiological confirmation and to regional differences in reporting sensitivity.

\section{Background}

Viruses are a common cause of central nervous system (CNS) infections in humans. There is increasing evidence that new neurotropic viruses, mostly of zoonotic origin, emerge regularly [1-5]. Many of these viruses can lead to outbreaks, thus increasing their public health importance $[3,4,6,7]$. Concrete data on the burden of different neurotropic infections are however limited [8].

In relation to neuroinvasive pathogens, all countries should have efficiently operating surveillance systems for aseptic central nervous system infections (ACI) in place that are able to identify potential threats and raise timely alarms, especially if international spread is involved. Enterovirus surveillance systems implemented in several countries have proved to be efficient alternatives to the acute flaccid surveillance and play an important role in the Global Polio Eradication Initiative $[8,9]$.

In Poland, a surveillance system aimed at the collection of generic information for all diagnosed and undiagnosed $\mathrm{ACl}$ cases was implemented in 1966. There is no official document in which operational objectives of the system are defined. For the purposes of this paper, we summarise the objectives of the system as follows, taking into consideration current national public health priorities: (i) monitoring overall $\mathrm{ACl}$ trends in order to detect outbreaks caused by neurotropic viruses (most commonly coxsackieviruses and echoviruses belonging to the Enterovirus family); (ii) identification and monitoring of tick-borne encephalitis (TBE) endemic areas in order to develop evidence-based TBE vaccination recommendations; (iii) monitoring Enterovirus strains and referring them for identification of polioviruses as part of the Global Polio Eradication Initiative; (iv) detection of signals indicating the possibility of emergence of neurotropic viruses not yet seen in Poland.

To achieve these objectives efficiently, the ideal surveillance system should perform well at both national and sub-national level, sensitively detect potential public health threats, and ensure regional availability of neuroinvasive virus diagnostics to enable timely and efficient interventions in situations such as enteroviral outbreaks, newly identified TBE foci or poliovirus spread.

The aim of the present study was to evaluate the $\mathrm{ACI}$ surveillance system in Poland according to selected performance indicators, with special focus on regional differences in its performance. 


\section{Material and methods}

The Polish ACI surveillance system is based on notifications from physicians. Physicians are required by law to notify suspected cases, i.e. those with signs of aseptic meningitis, encephalitis and/or myelitis, to the district sanitary-epidemiological stations (SES). Diagnosed $\mathrm{ACl}$ cases for which the viral aetiological agent has been identified, as well as cases classified as $\mathrm{ACl}$ of unknown aetiology or viral, unspecified $\mathrm{ACl}$ are reported to surveillance. Reports on incident $\mathrm{ACl}$ cases are aggregated and forwarded every two weeks to the provincial SES, where, in turn, they are aggregated and sent to the Department of Epidemiology at the National Institute of Public Health (PZH). Currently, each case is assigned to one of nine reporting categories based on the WHO International Classification of Diseases (ICD) (Table 1). Standardised case definitions are used for reporting of TBE and West Nile virus (WNV) infections. In case of TBE, a local case definition was developed [10], and for WNV the EU 2008 case definition was adopted [11].

In each of the 16 Polish provinces, laboratories in the public and private sector offer diagnostics for the most common $\mathrm{ACl}$ aetiological agents. Currently, the majority of laboratories receive payment for performing these tests, which are covered by the referring organisation. Only in some public health laboratories is testing of stool and cerebrospinal fluid for enteroviruses performed free of charge.

In the present paper we have summarised data on reported $\mathrm{ACl}$ cases, based on annual surveillance reports from 2004 to 2008 [12].To assess the availability of diagnostic testing for viral $\mathrm{ACl}$ aetiology we used the results from a survey on the availability of diagnostics for CNS infections conducted in the period from March to December 2009 and covering all Polish provinces. The respondents were 318 epidemiologists working in district SES. Each epidemiologist provided information from hospitals under their responsibility. From each hospital, information on the possibility to hospitalise $\mathrm{ACl}$ cases was requested, as well as on the availability of laboratory diagnostics for viral pathogens in the hospital or a subcontracted laboratory. We supplemented the above survey with information on the number of samples tested for viral pathogens in 2008 , obtained from an ad hoc survey of laboratories that were identified as offering $\mathrm{ACl}$ viral diagnostics in the main survey. We estimated the number of cases referred for diagnosis of $\mathrm{ACl}$ viral pathogens in each province. Because of the increasing role of magnetic resonance imaging $(\mathrm{MRI})$ in the diagnosis of herpes simplex encephalitis based on characteristic cerebral lesions [13], we also assessed the availability of MRI in Polish hospitals in the national hospitals registry [14]. All the above information on the availability of $\mathrm{ACl}$ diagnostics was collected for the year 2008. We assessed the differences between the 16 provinces by computing measures of location and dispersion (sum, mean, standard deviation, range, median and interquartile range). We compared the frequency of referral for diagnosis of viral aetiology with $\mathrm{ACl}$ incidence in each province through scatter plots and computation of Spearman correlation coefficients.

To assess the sensitivity of $\mathrm{ACl}$ surveillance during the studied period 2004 to 2008 , we compared aggregated data on $\mathrm{ACl}$ cases reported as part of routine surveillance with hospital discharge data that are collected annually from approximately $90 \%$ of Polish hospitals by the Department-Centre of Monitoring and Analyses of Population Health at PZH. In both systems ICD-10 codes are used to classify diagnosed diseases and syndromes, and for the present assessment we used five-digit codes used in the surveillance system (Table 1). Primary and up to five secondary causes

TABLE 1

List of diseases and syndromes reported in the Polish surveillance system for aseptic central nervous system infections

\begin{tabular}{|l|c|c|}
\hline ACl syndrome & $\begin{array}{c}\text { ICD-9 codes } \\
(1972-1996)\end{array}$ & ICD-10 codes \\
(1997-2008)
\end{tabular}

$\mathrm{ACl}$ : aseptic central nervous system infection. 
of hospitalisation included in the discharge records were extracted from the database and assigned to the patient's province of residence. To account for the diverse proportion of hospitals reporting monthly in particular Polish provinces, we weighted the annual number of hospitalised cases by province, with an underreporting factor constructed in the following way:

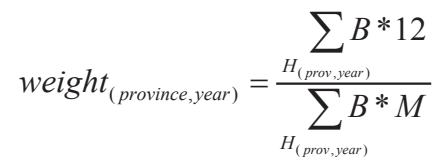

where $B$ is the number of hospital beds, $M$ the number of reporting months summed for hospitals in a given province in a given year, and $\mathrm{H}$ all registered hospitals in a given province in a given year.

We evaluated the sensitivity of statutory notifications by calculating the proportion of hospitalised cases that were reported to surveillance. We computed $95 \%$ confidence intervals $(\mathrm{Cl})$ of obtained sensitivity estimates using the formula for binomial proportions. For data analysis we used STATA version 10 [15].

\section{Results}

\section{Incidence of aseptic central}

nervous system infections

In the period 2004 to 2008 , aetiology was established for $17 \%$ of reported $\mathrm{ACl}$ cases in Poland. From the annual average of $1,951 \mathrm{ACl}$ cases reported, $238(12.2 \%)$ were diagnosed as TBE, 46 (2.4\%) as enteroviral, 35 (1.8\%) as herpes simplex $\mathrm{ACl}$, and $32(1.6 \%)$ as another viral cause such as Epstein Barr virus, adenovirus or other. It was presumed that the viral aetiology of an $\mathrm{ACl}$ with unknown cause was based on the general examination of cerebrospinal fluid, and MRI results.

The reported incidence of $\mathrm{ACl}$ differed considerably between Polish provinces in the period 2004 to 2008 (Figure 1). An almost 10 -fold difference was seen between provinces, with the lowest recorded in Lubuskie and the highest in Podlaskie (20.2 versus 191.4 per million inhabitants, $\mathrm{p}<10^{-4}$ ). This difference could be partly explained by the high TBE incidence in Podlaskie province, however after omitting confirmed TBE cases, the difference in incidence between the two provinces was still almost five-fold (20.2 versus 96.9 per million inhabitants, $\left.p<10^{-4}\right)$.

\section{Availability of diagnostics for aseptic central nervous system infections in hospitals}

According to the survey on the availability of $\mathrm{ACl}$ diagnostics, 185 of the 863 hospitals functioning in Poland in 2008 admitted $\mathrm{ACl}$ cases (301 wards). $\mathrm{ACl}$ cases were admitted predominantly to infectious disease and neurologic units, with occasional admissions to paediatric, internal medicine or intensive care units. Regional differences in the availability of $\mathrm{ACI}$ diagnostics were observed. The frequency of suspected $\mathrm{ACl}$ cases referred for viral aetiology investigation ranged from 1.98 to 285.4 samples per million inhabitants in the different provinces. Table 2 summarises the descriptive statistics for regional differences in diagnostic performance for $\mathrm{ACl}$.

Serological diagnosis of TBE was available in four laboratories in Poland, which offered ELISA testing for IgM and IgG antibodies against TBE virus. During 2008 , these laboratories processed serum or cerebrospinal fluid samples from 908 patients, of which 211 were found positive. Most of the tests were requested for suspected $\mathrm{ACl}$ cases living in high-risk areas for TBE, with $60.1 \%$ samples referred from three provinces where TBE incidence exceeded 5 per million inhabitants, and $91 \%$ samples referred from seven provinces where the TBE incidence was over 1 per million inhabitants (Figure 1). For enteroviral infections, serological diagnosis and isolation from stool samples were available in the 16 public health laboratories located in province capitals; PCR testing for these viruses was not available in Poland during the survey period. Of 568 samples referred for detection of antibodies against

\section{TABLE 2}

Selected indicators of the performance of diagnostics for aseptic central nervous system infections, Poland, 2004-2008

\begin{tabular}{|c|c|c|c|c|c|c|c|}
\hline & & Sum & Mean & SD & Range & Median & IQR \\
\hline \multirow{2}{*}{ Units hospitalising $\mathrm{ACl}$} & Total & 301 & 19 & 16 & $5-71$ & 13 & $11-22$ \\
\hline & Per million inhabitants & - & $7 \cdot 5$ & $3 \cdot 3$ & $3.5-5.2$ & 6.3 & $5.0-9.6$ \\
\hline \multirow{2}{*}{ Samples tested for TBE } & Total & 908 & 57 & 86 & $0-241$ & 16 & $5-57$ \\
\hline & Per million inhabitants & - & 34.6 & 61.4 & $0-202.3$ & $5 \cdot 5$ & $1.5-39.3$ \\
\hline \multirow{2}{*}{$\begin{array}{l}\text { Samples tested for } \\
\text { enteroviruses }\end{array}$} & Total & 568 & 36 & 37 & $0-118$ & 26 & $10-53$ \\
\hline & Per million inhabitants & - & 16.9 & $17 \cdot 5$ & $0-52.3$ & 11.7 & $3.6-25 \cdot 5$ \\
\hline \multirow{2}{*}{$\begin{array}{l}\text { Samples tested for other } \\
\text { viruses }\end{array}$} & Total & $718^{a}$ & 45 & 46 & $2-141$ & 27 & $10-66$ \\
\hline & Per million inhabitants & - & 20.1 & 22.9 & $2.0-82.3$ & 10.9 & $4.6-27.9$ \\
\hline
\end{tabular}

$\mathrm{ACI}$ : aseptic central nervous system infection; IQR: interquartile range; SD: standard deviation; TBE: tick-borne encephalitis.

a of which seven were tested for herpes simplex virus as well as for other viruses, adding up to 725 tests. 
enteroviruses in 2008, 57 were determined as positive. For confirmation of herpesviral CNS infections, MRI testing was available in 100 hospitals throughout the country, and PCR diagnosis, currently the reference diagnostic method to confirm herpes simplex virus infection, was offered by four laboratories (both paid for by the referring hospitals). According to our survey, 568 patients were tested for antibodies against herpes simplex virus, and 113 were found positive. Other aetiological agents of viral $\mathrm{ACl}$, including adenovirus, Epstein-Barr virus, cytomegalovirus, mumps, varicellazoster or measles viruses were investigated in 157 cases, of which 45 were found positive.
Sensitivity of reporting of aseptic central nervous system infections

The assessment of $\mathrm{ACl}$ reporting sensitivity is summarised in Table 3. From a total of 20,377 ACl cases recorded in Polish hospitals between 2004 and 2008, $9,754(47.9 \%)$ cases were reported to the national surveillance. Important differences in the surveillance sensitivity were observed by year, reporting syndrome, and province.

When the province-specific frequency of referral for viral aetiology diagnosis was compared with $\mathrm{ACl}$ incidence, we noted a statistically significant moderate

\section{FIGURE 1}

Average incidences of aseptic central nervous system infections per 1,000,000 inhabitants by province, Poland, 2004-2008

\section{A. Provinces in Poland}

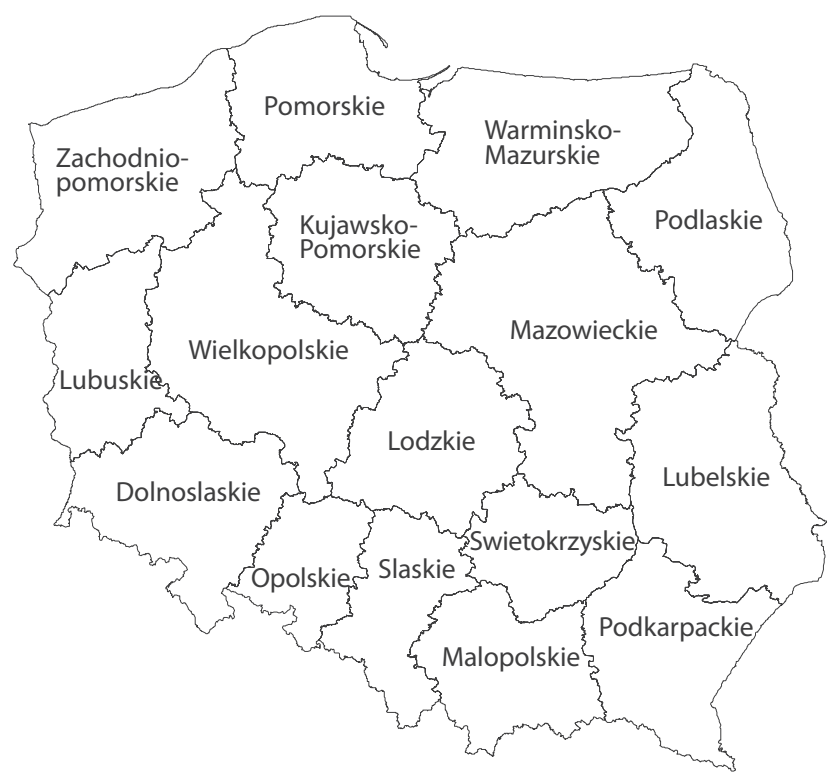

C. Tick-borne encephalitis

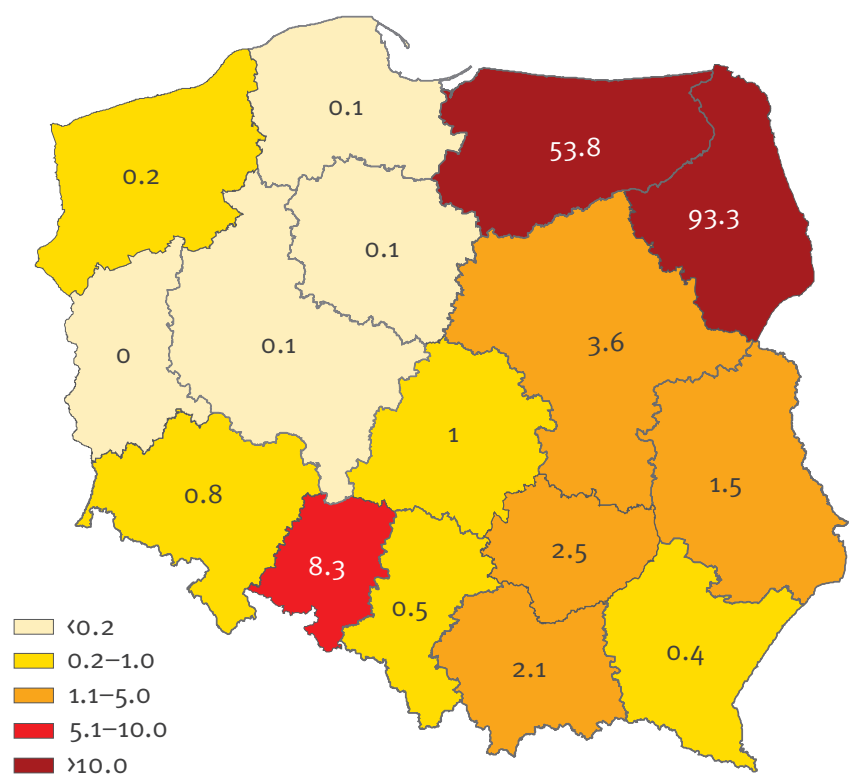

\section{B. Aseptic central nervous system infections}

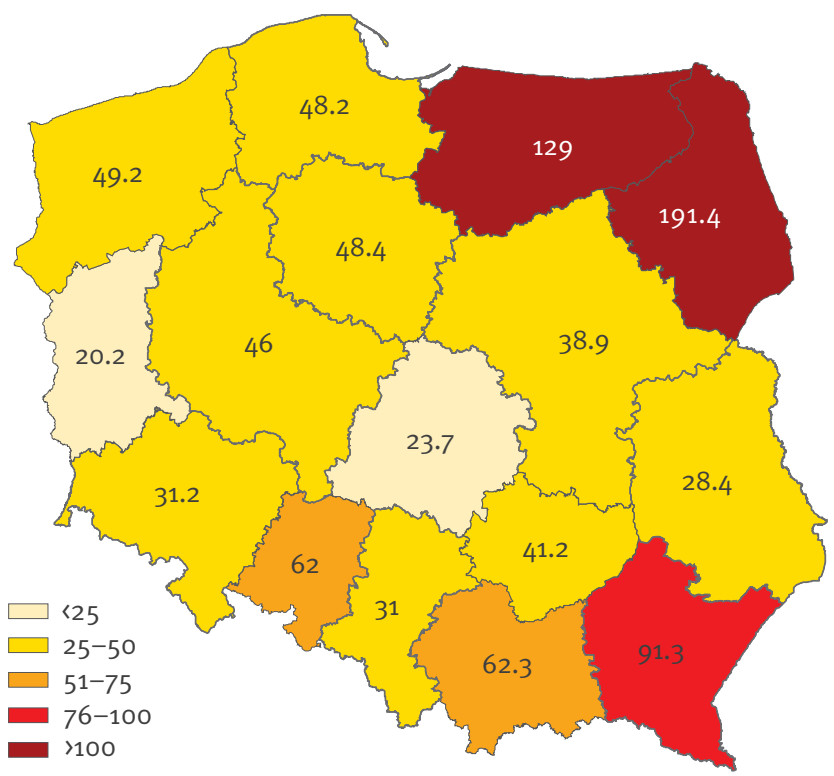

D. Enteroviral central nervous system infections

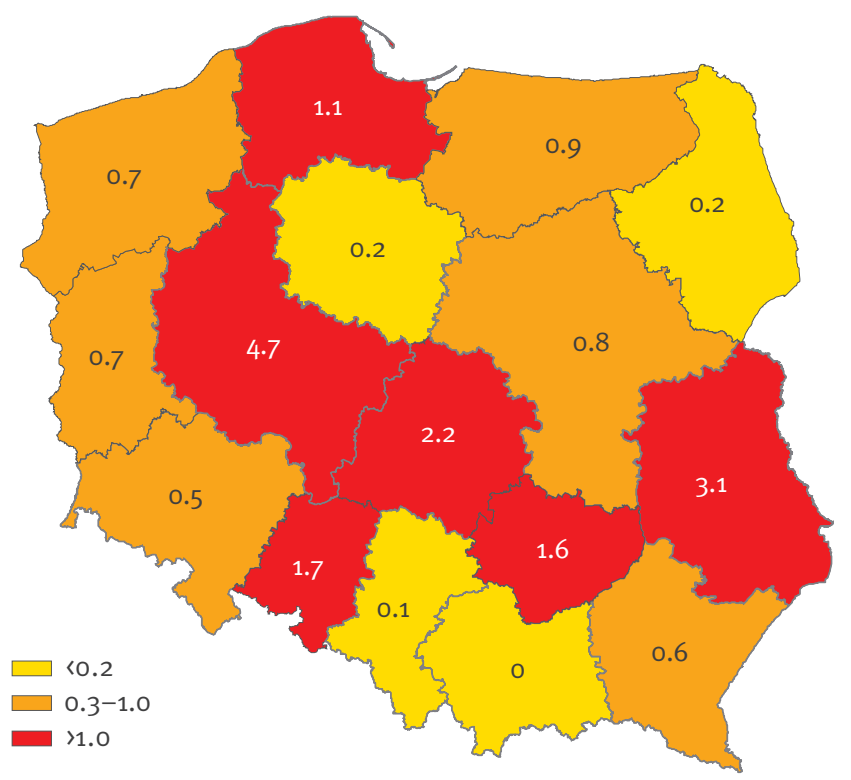


correlation with the incidence of reported $\mathrm{ACI}\left(\mathrm{r}_{\mathrm{s}}=0.62\right.$, $\mathrm{p}=0.011$ ) but no correlation with the incidence of hospitalised $\mathrm{ACl}\left(\mathrm{r}_{\mathrm{s}}=0.43, \mathrm{p}=0.0097\right)$. Plotting the regional frequency of referral for viral testing against the $\mathrm{ACl}$ incidence revealed that the same three provinces with known TBE endemic foci were clear outliers, both for hospitalised and reported $\mathrm{ACl}$ cases (Figure 2).

Figure 2. Frequency of referral for diagnosis of the viral aetiology of aseptic central nervous system infections in 16 provinces, Poland, 2004-2008

\section{Discussion}

In the present study we analysed the performance of the $\mathrm{ACl}$ surveillance system in Poland according to selected indicators. Combining data from different sources, we observed important regional differences in the system's performance. Aetiological diagnosis, a key factor in three of the four surveillance aims, was not uniformly available in all Polish provinces. Moreover, regional differences were observed in the physicians' approach towards reporting of $\mathrm{ACl}$ cases with specified or unspecified viral cause.

\section{TABLE 3}

Sensitivity of surveillance for aseptic central nervous system infections by reported syndrome, disease severity and province, Poland, 2004-2008 ( $\mathrm{n}=20,377$ hospitalised cases)

\begin{tabular}{|c|c|c|c|c|}
\hline & Hospitalised cases & Reported cases & Proportion reported & $95 \% \mathrm{Cl}$ \\
\hline \multicolumn{5}{|l|}{ Reported syndrome } \\
\hline Viral ACI, specified & 2,496 & 1,354 & 54.2 & $52.23-56.17$ \\
\hline Viral $\mathrm{ACl}$, unspecified & 9,055 & 6,258 & 69.1 & $68.12-70.03$ \\
\hline $\mathrm{ACl}$ other, unspecified & 8,826 & 2,142 & $24 \cdot 3$ & $23.37-25.17$ \\
\hline \multicolumn{5}{|l|}{ Reported disease severity } \\
\hline Meningitis & 16,190 & 6,894 & 42.6 & $41.82-43.35$ \\
\hline Encephalitis & 4,187 & 2,860 & 68.3 & $66.87-69.71$ \\
\hline \multicolumn{5}{|l|}{ Province } \\
\hline with lowest sensitivity & 1,019 & 304 & 29.8 & $27.04-32.75$ \\
\hline with highest sensitivity & 457 & 417 & 91.2 & $88.27-93.67$ \\
\hline
\end{tabular}

$\mathrm{ACl}$ : aseptic central nervous system infection; $\mathrm{Cl}$ : confidence interval.

\section{FIGURE 2}

Frequency of referral for diagnosis of the viral aetiology of aseptic central nervous system infections in 16 provinces, Poland, 2004-2008

A. Incidence based on hospital discharge registry

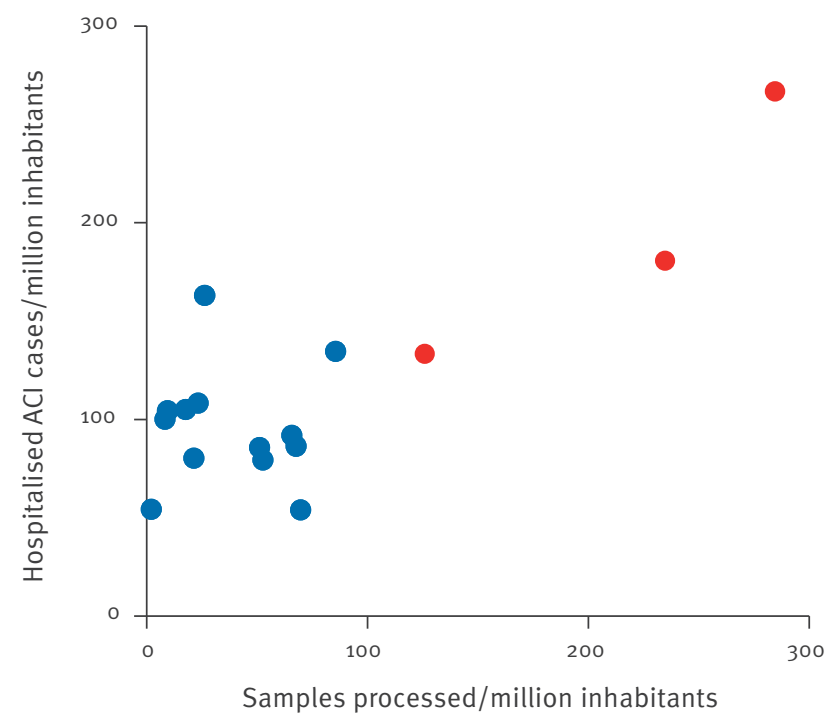

B. Incidence based on surveillance notifications

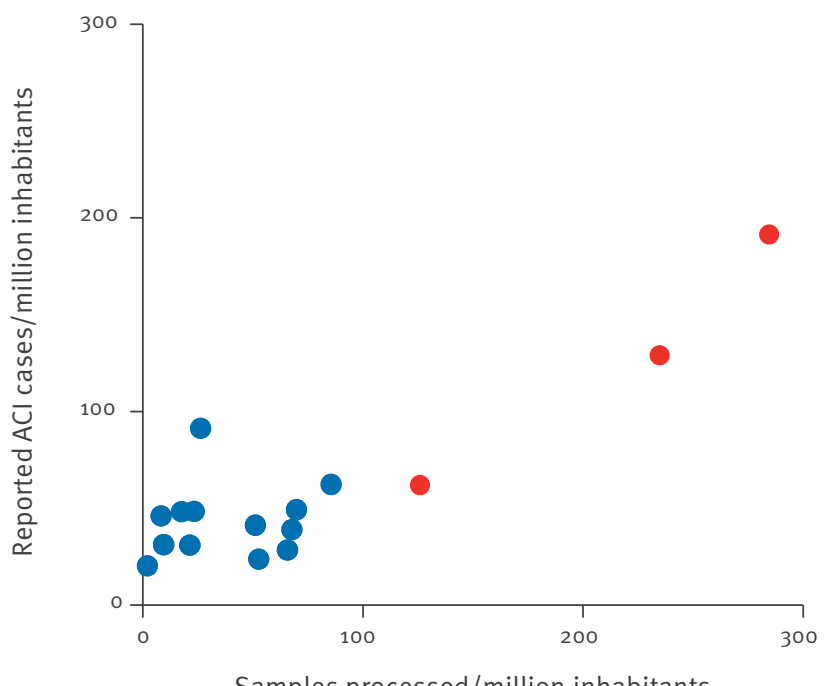

Samples processed/million inhabitants

$\mathrm{ACl}$ : aseptic central nervous system infection.

Red dots indicate provinces with tick-borne encephalitis incidence exceeding five cases per million inhabitants during $2004-2008$. 
Poor availability of aetiological diagnosis in Polish hospitals is an important limitation of the $\mathrm{ACl}$ surveillance system. Most Polish provinces are not able to reach any of the four stated surveillance objectives. Firstly, the public health system is probably not detecting the majority of enteroviral outbreaks, as only sporadic cases are diagnosed with enterovirus aetiology and the potential outbreak cases can remain undetected in the mass of undiagnosed cases. Secondly, the $\mathrm{ACl}$ surveillance system could be an efficient tool for detecting the location of TBE foci and monitoring its changes, if unspecified $\mathrm{ACl}$ cases were referred for testing in all provinces. In provinces not known for high TBE incidence, most locally acquired and imported TBE cases are not diagnosed and remain recorded in the surveillance system as $\mathrm{ACl}$ cases of unknown aetiology. Thirdly, it is highly unlikely that cases of polio would be differentiated from cases of aseptic meningitis, particularly if poliovirus is imported from endemic areas in Africa or Asia. Meningitis cases are rarely referred for enterovirus detection, and only as few as two strains and 18 samples for poliovirus isolation from $\mathrm{ACl}$ cases throughout the country were sent in 2008 to the National Polio Laboratory at the $\mathrm{PZH}$ (personal communication, Magdalena Wieczorek, July 2011). Finally, there is very little chance to detect the emergence of yet unknown viruses causing aseptic meningitis or encephalitis, because suspected $\mathrm{ACI}$ cases are rarely tested for viral aetiology. Valid monitoring of neurotropic viruses would require application of standard diagnostic protocols in Polish hospitals, and the possibility of cost-free referral of at least $10 \%$ of undiagnosed samples to regional or national reference laboratories.

We can hypothesise that Polish physicians may consider it an unnecessary cost to investigate the viral aetiology since no aetiological treatment is available for most viral $\mathrm{ACl}$ except herpes simplex CNS infections. Currently, the National Health Fund, which covers hospitalisation costs, offers the same refund for hospitalisation of $\mathrm{ACl}$ cases irrespective of whether the aetiology is confirmed or not. Sparse evidence from European studies indicates that diagnosis of viral pathogens as a cause of CNS infections is also rarely performed in other European countries $[8,16]$.

The regional differences in surveillance sensitivity across Polish provinces (mean 48\%, range 30-91\%) may be related to different levels of activity of local public health offices, and willingness of physicians to collaborate with the public health system. According to crude data, the highest reported $\mathrm{ACl}$ incidence, and some of the highest estimates of surveillance sensitivity were seen in provinces in which TBE diagnostics were widely available (data not shown). Sensitivity of reporting was lower for cases with milder symptoms (meningitis without signs of brain involvement), and for cases classified as 'other' and 'unspecified ACl', comprising all cases which could not be determined as either viral or bacterial.
Although national surveillance systems are the responsibility of the national authorities, there is increasing recognition of the need to collect supranational disease estimates and estimate the international disease burden, to better plan public health resources and detect public health threats. Because increasing international traffic facilitates the spread of infectious diseases, public health research should focus more on the setup and performance of national public health surveillance systems in order to better understand the meaning of numbers provided by the countries. If for example a new food- or waterborne viral strain appeared in a European setting, causing, among others, symptoms of meningitis, one would want to be sure of its timely detection, using standardised laboratory methods, in each country in which it appeared, before it spreads so far as to prevent efficient interventions.

The estimates presented here have several limitations. For the survey of $\mathrm{ACl}$ diagnostic availability, the SES did not approach hospitals that had not reported cases in a number of years, assuming that these did not hospitalise $\mathrm{ACl}$ cases but referred them elsewhere. Because not all hospitals comply with the procedures of reporting to the local SES, this could have led to underestimation of $\mathrm{ACl}$-hospitalising units. The ad hoc survey of $\mathrm{ACl}$ diagnostic testing performance was limited to the major diagnostic laboratories. We could therefore have missed samples referred for testing to other laboratories, for example in the private sector. Since the number of positive samples estimated by our survey matched closely the number of reported cases with established aetiology, we think that our estimates correctly reflect the diagnosis of $\mathrm{ACl}$ cases of probable viral aetiology in Poland. Also, the estimation of the physicians' notification sensitivity may be biased, as we compared two different data sources. The weighting factor did not take into account the type of unit in reporting hospitals. If hospitals that were not reporting discharge codes had fewer infectious disease or neurological departments than reporting hospitals, the weighted number of recorded $\mathrm{ACl}$ cases could have been overestimated. On the other hand, the majority of units that do not report to the hospital registry are university hospitals which have a higher frequency of admitted $\mathrm{ACl}$ cases compared to general hospitals. This would therefore lead to an underascertainment of hospitalised $\mathrm{ACl}$ cases.

To conclude, the Polish ACl surveillance system is not meeting most of its objectives, mainly because $\mathrm{ACl}$ aetiological diagnosis is not readily available to hospital physicians and because physicians' reporting is inconsistent. More research is necessary to understand the reasons for the poor compliance of physicians with mandatory reporting and for the regional differences in the performance of $\mathrm{ACl}$ surveillance. Furthermore, complete evaluation of the $\mathrm{ACl}$ surveillance system would be beneficial, using the criteria listed in the guidelines published by the United States Centers for Disease Control and Prevention [17]. Like 
other communicable disease surveillance systems in Poland, the $\mathrm{ACl}$ surveillance was implemented several decades ago, at a time when highly centralised surveillance systems were operating uniformly in all countries of the Warsaw Pact. Similar to other systems, ACl surveillance has never been evaluated, nor have its goals been stated. Polish society has gone through important changes during the past three decades and it is therefore important to understand whether the communicable disease surveillance objectives defined for the system more than 40 years ago are still valid.

\section{Recommendations}

Based on the results of the present evaluation we recommend the following:

1. Allocation of resources to improved diagnosis of $\mathrm{ACl}$ through, i.e. offering diagnosis for selected neurotropic viruses of public health importance in public health laboratories free of charge, or at least at reduced price;

2. Implementation of uniform diagnostic protocols in hospitals, including differential diagnosis of most common causes for $\mathrm{ACl}$ and their virological investigation;

3. Creation of a network of hospitals, from which cases would be referred for extended epidemiological and virological investigation of $\mathrm{ACl}$ cases in reference laboratories.

\section{Acknowledgements}

The authors wish to thank Hana Orlikova in her assistance in survey of ACl diagnostic availability, Natalia Parda for her assistance in data management and Anna Zielicka-Hardy for her helpful comments to the manuscript.
8. Donoso Mantke O, Vaheri A, Ambrose H, Koopmans M, de Ory F, Zeller H, Beyrer K, Windorfer A, Niedrig M, representing the European Network for Diagnostics of 'Imported' Viral Diseases (ENIVD) Working Group for Viral CNS Diseases. Analysis of the surveillance situation for viral encephalitis and meningitis in Europe. Euro Surveill. 2008;13(3):pii=8017. Available online: http://www.eurosurveillance.org/ViewArticle. aspx?Articleld $=8017$

9. Antona D, Lévêque N, Chomel JJ, Dubrou S, Lévy-Bruhl D, Lina B. Surveillance of enteroviruses in France, 2000-2004. Eur J Clin Microbiol Infect Dis. 2007;26(6):403-12. Eur J Clin Microbiol Infect Dis.2007 Jun;26(6):403-12.

10. Stefanoff P, Polkowska A, Giambi C, Levy-Bruhl D, O'Flanagan D, Dematte L, et al. Reliable surveillance of tickborne encephalitis in European countries is necessary to improve the quality of vaccine recommendations. Vaccine. 2011;29(6):1283-8.

11. European Commission. Commission decision of 19 March 2002 laying down case definitions for reporting communicable diseases to the Community network under Decision No $2119 / 98 / E C$ of the European Parliament and of the Council. $(2002 / 253 / E C)$. Official Journal of the European Communities 2002; L 86/44: 3 Apr 2002. Available from: http://eur-lex. europa.eu/LexUriServ/LexUriServ.do?uri=0J:L:2002:086:0044 :0062:EN:PDF

12. Infectious diseases and poisonings in Poland in 2008. Warsaw: National Institute of Public Health - National Institute of Hygiene, Chief Sanitary Inspectorate; 1999. [Accessed 20 Jul 2011]. Polish, partly in English. Available from: http://www. pzh.gov.pl/oldpage/epimeld/2008/Ch_2008.pdf

13. Boivin G. Diagnosis of herpesvirus infections of the central nervous system. Herpes 2004; 11 Suppl 2: 48A-56A.

14. Krajowy Rejestr Zakładów Opieki Zdrowotnej (National Register of Healthcare Institutions). Warsaw: Centre of Health Information Systems, Polish Ministry of Health. [Accessed 20 Jul 2011]. Polish. Available from: http://www.rejestrzoz.gov.pl/ RZOZ/

15. StataCorp 2007. Stata Statistical Software: Release 10. College Station, TX: StataCorp LP.

16. Haglund M, Settergren B, Heinz FX, Günther G; ISW-TBE Study Group. Report of the Meningitis Program of the International Scientific Working Group on TBE. Serological screening of patients with viral CNS-infection of unknown etiology in search of undiagnosed TBE cases. Vaccine 2003;21 Suppl 1:S66-72.

17. Centers for Disease Control and Prevention. Updated guidelines for evaluating public health surveillance systems: recommendations from the guidelines working group. MMWR 2001;50(No. RR-13).

References

1. Jones KE, Patel NG, Levy MA, Storeygard A, Balk D, Gittleman JL, Daszak P. Global trends in emerging infectious diseases. Nature 2008; 451: 990-3.

2. Mackenzie JS. Emerging zoonotic encephalitis viruses: lessons from Southeast Asia and Oceania. J Neurovirol. 2005 Oct;11(5):434-40.

3. Wong KT. Emerging epidemic viral encephalitides with a special focus on henipaviruses. Acta Neuropathol. 2010 Sep;120(3):317-25.

4. Zeller H, Lenglet A, Van Bortel W. West Nile virus: the need to strengthen preparedness in Europe. Euro Surveill. 2010;15(34):pii=19647. Available online: http://www. eurosurveillance.org/ViewArticle.aspx?Articleld=19647

5. Charrel RN, Gallian P, Navarro-Mari JM, Nicoletti L, Papa A, Sánchez-Seco MP, Tenorio A, de Lamballerie X. Emergence of Toscana virus in Europe. Emerg Infect Dis 2005; 11(11): 1657-63.

6. Ćosić G, Durić P, Milošević V, Đekić J, Čanak G, Turkulov V. Ongoing outbreak of aseptic meningitis associated with echovirus type 30 in the City of Novi Sad, Autonomous Province of Vojvodina, Serbia, June - July 2010. Euro Surveill. 2010;15(32):pii=19638. Available online: http://www. eurosurveillance.org/ViewArticle.aspx?Articleld $=19638$

7. Sun LM, Zheng HY, Zheng HZ, Guo X, He JF, Guan DW, Kang M, Liu Z, Ke CW, Li JS, Liu L, Guo RN, Yoshida H, Lin JY. An enterovirus 71 epidemic in Guangdong Province of China, 2008: epidemiological, clinical, and virogenic manifestations. Jpn J Infect Dis 2011; 64(1): 13-8. 